\title{
PENINGKATAN KETERAMPILAN PROSES SAINS MENGGUNAKAN MODEL INKUIRI PADA MATERI REDOKS SMA BUKIT BATU RIAU
}

\section{IMPROVING SKILLS OF SCIENCE PROCESS USING INKUIRI MODEL ON THE MATERIAL REDOKS AT SMA BUKIT BATU RIAU}

\author{
Suherni*, Julia Maulina, Dian Nirwana Harahap \\ Universitas Islam Sumatera Utara, Department of Chemistry Education, Medan 20217, \\ North Sumatera, Indonesia \\ *Corresponding author: annebroo6@gmail.com
}

\begin{abstract}
ABSTRAK
Penelitian ini bertujuan untuk menganalisa peningkatan keterampilan proses sains melalui model pembelajaran inkuiri dan untuk mengetahui aspek rata-rata keterampilan proses sains siswa yang terukur melalui model pembelajaran inkuiri pada materi redoks . Desain penelitian ini menggunakan model penelitian tindakan kelas (PTK). Instrumen dalam penelitian ini adalah menggunakan instrumen tes keterampilan sains dalam bentuk non tes berupa lembar observasi dan tes berupa uraian. Tes keterampilan proses sains yang digunakan dalam penelitian ini meliputi keterampilan berkomunikasi, keterampilan merumuskan masalah, keterampilan menggunakan alat dan bahan, keterampilan meramalkan (prediksi), keterampilan mengamati (observasi), keterampilan menafsirkan (interpretasi) dan keterampilan mengelompokkan (klarisikasi). Proses Sains yang terukur terlihat bahwa aspek mengamati (observasi) merupakan aspek yang tertinggi yang dicapai oleh siswa yaitu dengan nilai rata- rata $91 \%$. aspek merumuskan masalah merupakan aspek yang terendah yang dicapai siswa yaitu dengan nilai rata- rata $74 \%$. Sedangkan peningkatan hasil belajar diperoleh nilai sebesar 0,52 dan dikategorikan sedang.
\end{abstract}

Kata Kunci : Keterampilan Proses Sains, Inkuiri, Materi Redoks

\begin{abstract}
This research aims to analyze the science process skills improvement through model learning inkuiri and to find out the average skills aspect of the process of science students are learning models through scalable inkuiri on redox materials. This design research research using model action class (PTK).. Science process skills test used in the study include the skills of communicating, the skills to formulate problems, skills using tools and materials, skill forecasting (prediction), the skills to observe (observation), skills of interpreting (interpretation) and pegging skills (klarisikasi). Scalable science process seem that aspects of the observed (observation) is an aspect of the highest achieved by students with an average score of $91 \%$. aspects of formulating a problem is an aspect of the lowest achieved students with an average score of $74 \%$. Whereas the improvement of the learning outcomes acquired value of 0.52 and categorized.
\end{abstract}

Keywords: Science Process Skills, Inkuiri, Redox Materials 


\section{PENDAHULUAN}

Keterampilan proses sains dalam pembelajaran kimia melibatkan kemampuan kognitif, afektif dan psikomotorik. Kemampuan kognitif (minds on) karena dalam pembelajaran peserta didik berpikir, kemampuan psikomotor (hands on) karena peserta didik terlibat dalam menggunakan alat dan bahan, pengukuran, penyusunan atau perakitan alat, dan kemampuan afektif (hearts on) karena peserta didik berinteraksi dengan sesamanya dalam melaksanakan kegiatan belajar mengajar.

Berdasarkan hasil observasi di SMA Negeri 3 Bukit Batu Riau, diperoleh bahwa pelaksanaan pembelajaran kimia masih cenderung dilakukan dengan cara konvensional. Guru lebih banyak menerangkan pada saat menyampaikan materi, yang disertai dengan tanya jawab dan pemberian tugas. Sebagian besar waktu belajar peserta didik dihabiskan untuk mendengarkan ceramah guru, menghafal dan mencatat materi. Praktikum masih jarang dilakukan karena kesibukan guru dan tidak adanya laboran yang dapat membantu guru mempersiapkan praktikum, padahal aktivitas peserta didik di dalam laboratorium lebih efektif melatih keterampilan proses, mengembangkan sikap ilmiah dan meningkatkan pemahaman materi.

Selain prestasi belajar yang masih relatif rendah, penulis menemukan beberapa permasalahan yang muncul dalam proses pembelajaran, seperti; sebagian besar siswa tidak melaksanakan literasi, selama proses pembelajaran berlangsung hanya sedikit peserta didik yang berani bertanya kepada guru, sebagian besar kesulitan untuk merancang prosedur dan tabel data pengamatan, menganalisa data secara akurat dan mendalam serta menarik kesimpulan berdasarkan data.

Untuk mengatasi masalah diatas, perlu diterapkan suatu model pembelajaran yang dapat mengaktifkan siswa, sehingga masalah dalam kesulitan proses belajar mengajar dapat diatasi dengan baik, pembelajaran yang dimaksud adalah pembelajaran yang tidak hanya mampu dengan materi saja tetapi mampu menekankan kepada proses keterlibatan siswa secara penuh untuk dapat mengkaitkan dengan situasi kehidupan nyata sehingga mendorong siswa untuk dapat menerapkannya dalam kehidupan sehari- hari.

Berdasarkan hasil temuan penelitian Wenni Jayanti, dkk (2013) disimpulkan bahwa keterampilan proses sains peserta didik SMAN 1 Rasau Jaya Kelas X pada pembelajaran Redoks dengan metode inkuiri dikategorikan sangat baik. Hal ini menunjukkkan bahwa keterampilan proses sains peserta didik dapat terlihat ketika pembelajaran dilakukan dengan menggunakan praktikum. Solusi yang mampu mengembangkan keterampilan proses sains peserta didik adalah suatu model pembelajaran yang dapat mengaktifkan peserta didik dalam kegiatan pembelajaran sehingga terjadi interaksi antara guru dengan peserta didik, peserta didik dengan peserta didik dan peserta didik dengan sumber maupun media belajar. Salah satu model pembelajaran dapat yang dapat digunakan adalah model inkuiri.

Semiawan dalam Wenni Jayanti (2013 : 1 - 2) merinci kemampuan-kemampuan yang dapat dikembangkan dalam keterampilan proses antara lain mengamati (observasi), membuat hipotesa, merencanakan penelitian, mengendalikan variabel, menafsirkan data (interpretasi), menyusun kesimpulan sementara (inferensi), meramalkan (prediksi), menerapkan (aplikasi) dan mengkomunikasikan. Model pembelajaran yang dapat digunakan untuk meningkatkan keterampilan proses sains dan berpusat pada siswa, salah satunya adalah model pembelajaran inkuiri .

Kegiatan pembelajaran inkuiri ditujukan untuk menambah kemampuan siswa dalam menggunakan keterampilan proses dengan merumuskan pertanyaan yang mengarah pada kegiatan investigasi, merumuskan hipotesis, mengumpulkan data, analisis data, dan membuat kesimpulan. Inkuiri merupakan model pembelajaran berbasis kontekstual, yang dalam penerapannya dilakukan proses penemuan atau penyelidikan untuk memecahkan suatu masalah dengan bimbingan dari guru (Trianto dalam Ulya Dewi Annur, dkk 2013: 2).

Beberapa hasil penelitian menunjukkan model inkuiri dapat meningkatkan keterampilan proses sains siswa. Berdasarkan hasil penelitian Nanda Maikristina, dkk (2013), keterampilan proses sains siswa yang dibelajarkan menggunakan model pembelajaran inkuiri terbimbing memiliki ketercapaian yang lebih baik daripada siswa yang dibelajarkan menggunakan model problem solving. Ulya Dewi Annur, 
dkk (2013) menyimpulkan pembelajaran inkuiri dapat meningkatkan keterampilan proses sains dan hasil belajar siswa. Pembelajaran inkuiri juga dapat diterapkan dalam kegiatan praktikum. Menurut Luluk Mufidah (2014: 19) praktikum di laboratorium dapat menjadi strategi untuk mengkonkritkan konsepkonsep yang abstrak dalam pembelajaran inkuiri.

Keterampilan proses sains peserta didik dapat terlihat ketika pembelajaran dilakukan dengan menggunakan praktikum. Solusi yang mampu mengembangkan keterampilan proses sains peserta didik adalah suatu model pembelajaran yang dapat mengaktifkan peserta didik dalam kegiatan pembelajaran sehingga terjadi interaksi antara guru dengan peserta didik, peserta didik dengan peserta didik dan peserta didik dengan sumber maupun media belajar. Salah satu model pembelajaran yang dapat digunakan adalah model inkuiri.

\section{METODE PENELITIAN}

\subsection{Jenis Penelitian}

Penelitian ini menggunakan metode Penelitian Tindakan kelas (PTK) atau yang lebih dikenal dengan sebutan Classroom Action Reserch.

\subsection{Waktu dan Tempat Penelitian}

Penelitian ini dilaksanakan pada pertengahan bulan Maret 2019 sampai dengan akhir bulan April 2019 dan tempat penelitian dilaksanakan pada SMA Negeri 3 Bukit Batu Riau.

\subsection{Target / Subjek Penelitian}

Siswa kelas X MIPA SMA Negeri 3 Bukit Batu Riau

\subsection{Prosedur}

Desain penelitian tindakan kelas ini dapat dilaksanakan melelui beberapa siklus sampai indikator keberhasilan tercapai. Jika indikator keberhasilan telah tercapai, maka penelitian ini akan dihentikan. Penelitian ini dilakukan dalam dua siklus, masing-masing siklus dilaksanakan dalam dua kali tatap muka. Pada pertemuan pertama siklus I membahas konsep reaksi reduksi-oksidasi, sedangkan pada pertemuan kedua membahas materi zat oksidator dan reduktor. Selanjutnya setelah dilakukan refleksi terhadap pelaksanaan kegiatan pembelajaran pada siklus I dilanjutkan pelaksanaan siklus II. Pada pertemuan pertama siklus II membahas materi reaksi redoks yang dapat berlangsung dan tidak dapat berlangsung, sedangkan pada pertemuan kedua membahas materi tatanama senyawa IUPAC dan aplikasi reaksi redoks dalam memecahkan masalah lingkungan.

\subsubsection{Siklus I}

a. $\quad$ Fase Perencanaan (plant)

Pada tahap perencanaan ini dilakukan persiapan yang berhubungan dengan pelaksanaan pembelajaran inkuiri, seperti identifikasi masalah,pembuatan rencana pembelajaran (RPP), pembuatan lembar kerja peserta didik (LKPD), penyediaan alat yang akan digunakan untuk percobaan.

b. Fase Tindakan (act)

Pelaksanaan tindakan merupakan kegiatan dilaksanakannya skenario pembelajaran yang telah direncanakan. Adapun tindakan yang dilakukan oleh guru adalah memberi tugas mandiri kepada siswa, membentuk kelompok, membimbing siswa melakukan percobaan, serta memberikan tes di akhir siklus.

Pelaksanaan tindakan dilakukan dengan menggunakan model inkuiri untuk meningkatkan keterampilan proses sains dan keterampilan karakter siswa. Pada model pembelajaran inkuiri guru sedapat mungkin mengembangkan keterampilan siswa akan belajar lebih bermakna dengan cara bekerja sendidri, menemukan sendiri, dan mengkonstruksi pengetahuan dan keterampilan baru, mengembangkan rasa ingin tahu siswa dengan bertanya, dan melaksanakan refleksi pada akhir pertemuan pembelajaran, dan melakukan penilaian. 
c. Fase Pengamatan (observe)

Pengamatan adalah suatu kegiatan mengamati jalannya pelaksanaan tindakan untuk memantau sejauh mana efek tindakan pembelajaran dengan menggunakan model pembelajaran inkuiri pada pokok materi redoks dengan menggunakan lembar observasi.

d. Fase Refleksi (reflect)

Fase ini dilakukan pada akhir siklus dengan tujuan mengevaluasi keterlaksanaan setiap tindakan. Refleksi ini dilanjutkan dengan revisi perencanaan untuk memperbaiki atau memodifikasi tindakan pada siklus I yang akan diimplementasikan pada siklus selanjutnya (siklus II).

\subsubsection{Siklus II}

Desain penelitian pada siklus II sama seperti desain penelitian pada siklus I. Hanya saja, pada siklus II berdasarkan pada perbaikan dan revisi pada siklus I. (Diah Kusumaningsih, 2011).

\subsection{Data, Instrumen, dan Teknik Pengumpulan data}

Instrumen yang digunakan dalam penelitian ini adalah 1) RPP yang akan dijadikan panduan dalam kegiatan pembelajaran yang disusun dalam skenario pembelajaran (terlampir). 2) Lembar Kerja Peserta Didik (LKPD) sebagai petunjuk kerja praktikum untuk mengembangkan keterampilan siswa (terlampir). 3) Lembar Observasi yang dilakukan secara terstruktur, yaitu observasi yang telah dirancang secara sistematis dimana semua aktivitas observer dan materi observasi telah ditetapkan dan dibatasi dengan jelas dan tegas. Observasi ini dilakukan secara langsung terhadap peserta didik selama kegiatan pembelajaran berlangsung dengan menggunakan pedoman observasi yang didalamnya memuat format penilaian dan kriteria-kriteria keterampilan proses sains peserta didik yang akan diamati. Selanjutnya data pada lembar observasi tersebut digunakan sebagai data yang akan dianalisis. 4) Pedoman Wawancara dengan bentuk pertanyaan tak terstruktur, yaitu pertanyaan yang bersifat terbuka dimana responden secara bebas menjawab pertanyaan tersebut. Pedoman wawancara dibuat sebagai panduan dalam melakukan wawancara nantinya berdasarkan keterampilan proses sains.

Teknik pengumpulan data adalah tahap-tahap yang dilakukan peneliti dalam mengumpulkan data penelitiannya. Tahapan tersebut adalah berupa tes keterampilan proses sains dalam bentuk non-tes berupa lembar observasi dan tes uraian (subjektif). Tes keterampilan proses sains yang digunakan dalam penelitian ini meliputi, berkomunikasi, merumuskan masalah, pengguanaan alat dan bahan, observasi, berhipotesis, interpretasi, dan menyimpulkan, dimana pada lembar observasi ini akan dilakukan penilaian pada peserta didik secara langsung menggunakan pedoman observasi dengan range skala penilaian 1-5 selama kegiatan pembelajaran dengan model inkuiri berlangsung, dimana metode pembelajaran yang digunakan adalah praktikum. Penilaian dilakukan sebanyak empat kali, sehingga diperoleh empat data hasil penilaian keterampilan proses sains peserta didik. Sedangkan tes uraian (subjektif) dilaksanakan pada setiap akhir siklus dengan jumlah soal siklus I sebanyak 12 soal dan siklus II sebanyak 12 soal. Penilaian hasil tes uraian digunakan untuk menghitung kenaikan hasil belajar siswa.

\subsection{Teknik Analisa Data}

Teknik analis data observasi keterampilan proses sains pada tiap siklus mengacu pada rumus Arikunto, dkk (2007) yaitu:

$$
\% \text { keterampilan proses }=\frac{\sum \text { skor keterampilan proses }}{\sum \text { skor maksimal }} \times 100
$$

Selanjutnya Menentukan kategori keterampilan proses sains peserta didik berdasarkan skala kategori keterampilan sebagai berikut: 
Tabel 1. Skala Kategori Keterampilan Proses Sains

\begin{tabular}{cc}
\hline Nilai (\%) & Kategori Keterampilan \\
\hline $0,00-20,00$ & Sangat kurang \\
\hline $20,00-39,99$ & Kurang \\
\hline $40,00-59,99$ & Cukup \\
\hline $60,00-79,99$ & Baik \\
\hline $80,00-100,00$ & Sangat baik
\end{tabular}

(Suharsimi Arikunto, 2006: 241)

Setelah menghitung skor rata-rata keterampilan proses sain siswa maka dilakukan penghitungan skor Gain yang mengacu pada Hake (Iswanto, 2012:32) secara matematis dapat dituliskan sebagai berikut:

$$
\langle\mathrm{g}\rangle=\frac{(\text { skor tes siklus } k e-i+1)-(\text { skor tes siklus } k e-i)}{(\text { skor maksimum })-(\text { skor tes siklus } k e-i)}
$$

Setelah menghitung skor Gain, kemudian Menginterpretasikan skor rata-rata Gain ternormalisasi dengan menggunakan tabel berikut.

Tabel 2. Interpretasi Gain yang Ternormalisasi

\begin{tabular}{cc}
\hline Nilai $<\mathbf{g}>$ & Interpretasi \\
\hline $0,00-0,30$ & Rendah \\
\hline $0,31-0,70$ & Sedang \\
\hline $0,71-1,00$ & Tinggi \\
\hline
\end{tabular}

Sedangkan untuk Pengolahan uji tes (tes uraian) keterampilan proses sains data dianalisis dengan cara sebagai berikut:

a. Skor yang diperoleh siswa menjawab dengan benar dapat menggunakan rumus penskoran sebagai berikut:

$$
\text { Skor }=\frac{\text { soal yang dijawab benar }}{\text { skor total }} \times 100
$$

b. Menghitung persentase aspek KPS dengan menggunakan rumus

$$
\%=\frac{\text { rata }- \text { rata skor }}{\text { skor maksimal }} \times 100
$$

Setelah menghitung skor dan rata-rata, maka dilakukan analisis peningkatan hasil belajar dengan rumus sebagai berikut.

1) Rata-rata kelas

$$
\begin{aligned}
& \text { Rumus : } \mathrm{X}=\frac{\sum N}{n} \\
& \text { Ketarangan } \\
& \mathrm{X} \quad \text { : nilai rata-rata kelas }
\end{aligned}
$$


$\sum \mathrm{N} \quad$ : total nilai yang diperoleh siswa

$\mathrm{N} \quad$ : jumlah siswa

2) Persentase Ketercapaian KKM

$\begin{array}{lll}\text { Rumus } & : \text { TB }=\frac{\sum s \geq 70}{n} \times 100 \% & \text { Purwanto (Iswanto, 2012:32) } \\ \text { Keterangan: } & & \text { : Ketuntasan Belajar } \\ \text { TB } & : \text { jumlah siswa yang mendapatkan nilai lebih besar dari atau sama dengan } 70 \\ \sum_{\mathrm{n}} \mathrm{S} \geq 70 & : \text { jumlah siswa } & \text { : bilangan tetap. }\end{array}$

\section{HASIL DAN PEMBAHASAN}

\subsection{Data Hasil Observasi}

\subsubsection{Data Obsevasi Siklus I}

\subsubsection{Materi Konsep Redoks}

Data hasil observasi materi konsep redoks dapat dilihat pada gambar 1 sebagai berikut:

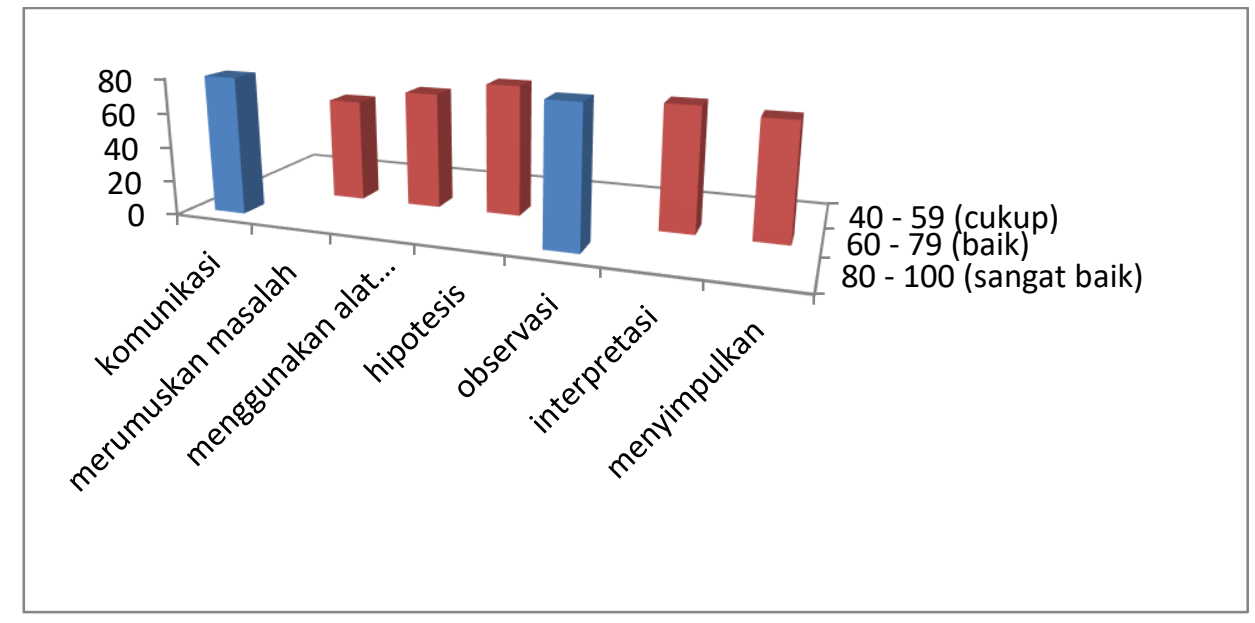

Gambar 1. Hasil tes observasi materi konsep redoks

Gambar 1. menunjukkan bahwa dengan model pembelajaran inkuiri pada materi redoks , sebanyak 20,58\% siswa (7 orang siswa) memiliki kerampilan proses sains dengan kategori sangat baik dan ada 51,45\% siswa (16 orang siswa) dengan kategori baik. Siswa yang memiliki ketrampilan proses dengan kategori persentase skor tertinggi yaitu $80 \%$ adalah pada aspek berkomunikasi dan observasi. Pada aspek berkomunikasi siswa mampu menyampaikan tanggapan tentang perubahan warna pada buah apel yang telah dikupas, sedangkan pada aspek observasi siswa dapat membedakan perubahan warna pada keempat irisan buah apel yang telah ditambahkan air jeruk nipis, air garam dan cuka. Siswa yang memiliki ketrampilan proses dengan persentase terendah yaitu $60 \%$ adalah pada aspek merumuskan masalah, hal ini disebabkan a) siswa tidak mampu menjawab dengan benar tentang penambahan bahan yang baik untuk mempertahankan reaksi oksidasi yang menyebabkan pencoklatan pada apel (oksidasi), b) tidak mampu menjawab dengan benar apakah fotosintesis menghasilkan oksigen $\left(\mathrm{O}_{2}\right)$ dan termasuk reaksi reduksi. Pada observasi yang pertama ini rata-rata keterampilan proses sains siswa pada materi konsep redoks dikategorikan baik. 


\subsubsection{Materi Reduktor Oksidator}

Data hasil observasi materi reduktor/oksidator dapat dilihat pada grafik 2 sebagai berikut:

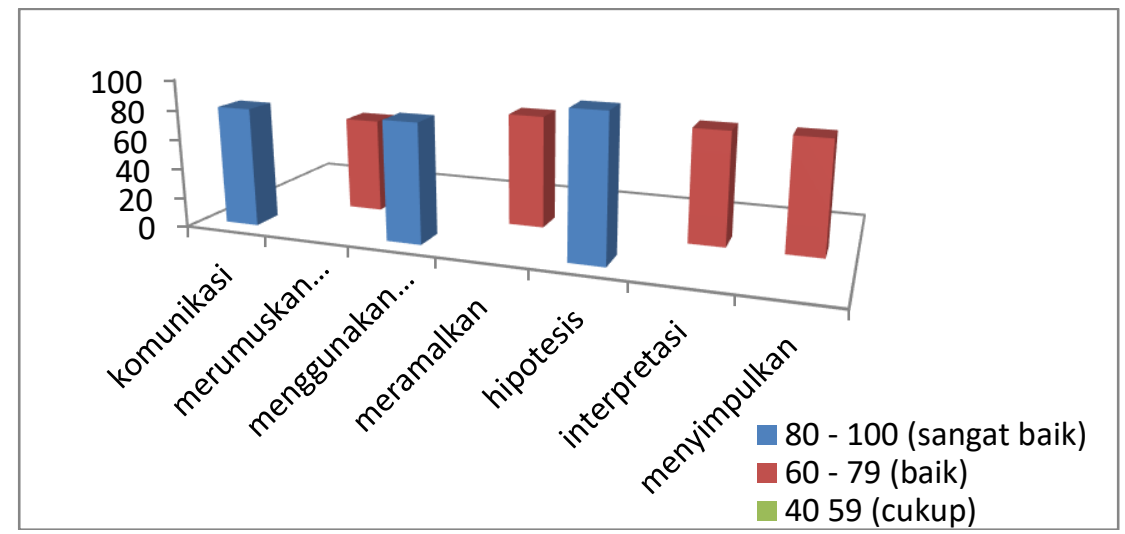

Gambar 2. Hasil tes observasi materi oksidator reduktor

Gambar 2. menunjukkan bahwa dengan model pembelajaran inkuiri pada materi redoks , sebanyak 33,42\% siswa (10 orang siswa) memiliki kerampilan proses sains dengan kategori sangat baik dan ada 44,56\% siswa (13 orang siswa) dengan kategori baik. Siswa yang memiliki ketrampilan proses dengan persentase skor tertinggi yaitu $96 \%$ adalah pada aspek observasi. Pada aspek observasi siswa dapat membedakan perubahan gejala perkaratan paku yang telah ditambah dengan air, air garam, minyak dan air jeruk. Siswa yang memiliki ketrampilan proses dengan persentase terendah yaitu $64 \%$ adalah pada aspek merumuskan masalah, hal ini disebabkan siswa tidak dapat menjawab mengapa logam (paku) dapat berkarat. Pada observasi yang kedua ini rata-rata keterampilan proses sains siswa pada materi reduktor oksidator dikategorikan baik.

\subsubsection{Data Hasil Observasi Siklus II}

\subsubsection{Materi Reaksi redoks dapat/tidak berlangsung}

Data hasil observasi materi redoks dapat/tidak berlangsung dapat dilihat pada gambar 3 sebagai berikut. 


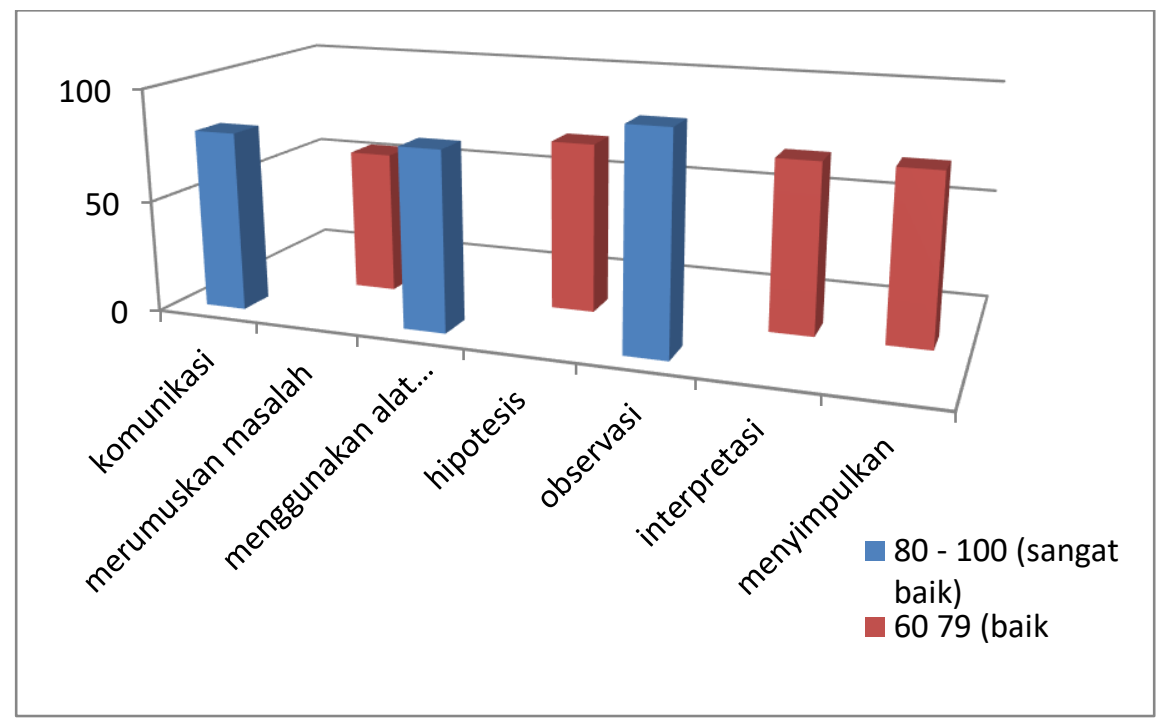

Gambar 3. Hasil tes observasi materi redoks dapat/tidak berlangsung

Gambar 3. menunjukkan bahwa dengan model pembelajaran inkuiri pada materi redoks, sebanyak 84\% siswa (23 orang siswa) memiliki kerampilan proses sains dengan kategori sangat baik. Siswa yang memiliki ketrampilan proses dengan persentase skor tertinggi yaitu $88 \%$ adalah pada aspek observasi dan menggunakan alat dan bahan. Pada aspek observasi siswa mampu membedakan perubahan gejala pada logam $\mathrm{Zn}, \mathrm{Cu}, \mathrm{Fe}$ yang direaksikan dengan larutan $\mathrm{CuSO}_{4}$ dan larutan $\mathrm{ZnSO}_{4}$, sedangkan pada aspek menggunakan alat dan bahan siswa mampu menggunakan larutan $\mathrm{CuSO}_{4}$ dan larutan $\mathrm{ZnSO}_{4}$ dengan efisien dan benar. Siswa yang memiliki ketrampilan proses dengan persentase terendah yaitu $80 \%$ (sangat baik) adalah pada aspek meramalkan/hipotesis dan menyimpulkan. Pada aspek meramalkan/hipotesis siswa mampu memprediksi perubahan logam sebelum dilakukan percobaan, sedangkan pada aspek menyimpulkan siswa mampu membandingkan hasil pengamatan yang diperoleh dengan teori. Pada observasi yang ketiga ini rata-rata keterampilan proses sains siswa pada materi redoks dapat/tidak berlangsung dikategorikan sangat baik.

\subsubsection{Materi Tatanama Senyawa}

Data hasil observasi materi tatanama senyawa dapat dilihat pada gambar 4 sebagai berikut.

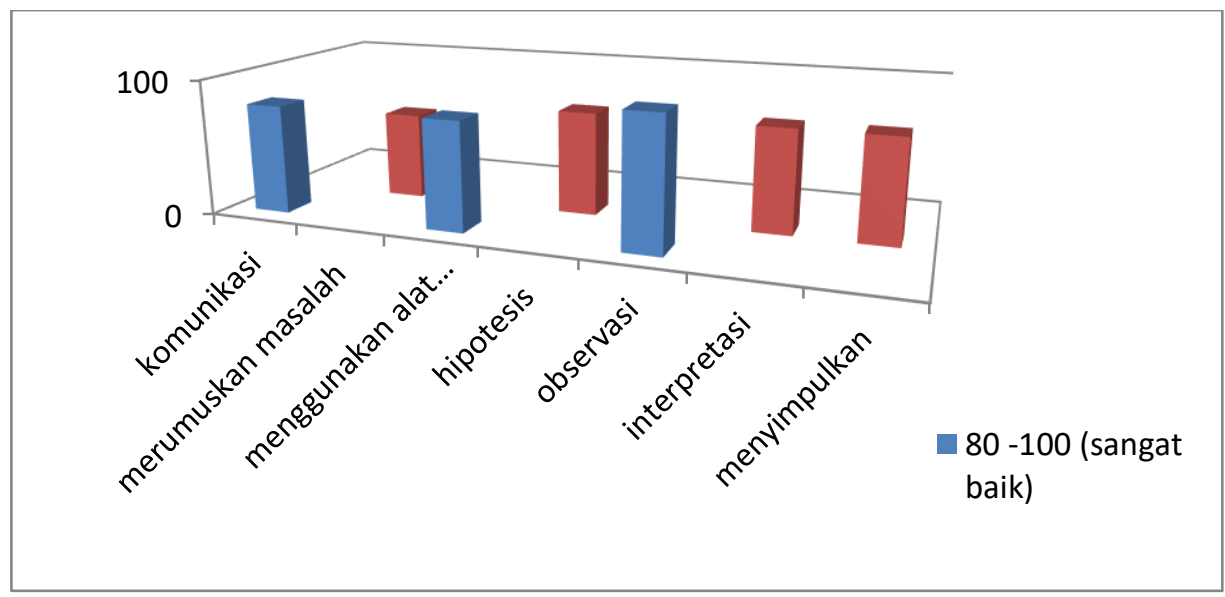

Gambar 4. Hasil tes observasi materi tatanama senyawa 
Gambar 4 menunjukkan bahwa dengan model pembelajaran inkuiri pada materi redoks, sebanyak $90 \%$ siswa (23 orang siswa) memiliki kerampilan proses sains dengan kategori sangat baik. Siswa yang memiliki ketrampilan proses dengan persentase skor tertinggi yaitu $100 \%$ (sangat baik) adalah pada aspek observasi dan menyimpulkan. Pada aspek observasi siswa mampu membedakan angka bilangan oksidasi pada unsur yang ada dalam tabel LKPD, sedangkan pada aspek menyimpulkan siswa mampu menuliskan beberapa senyawa nama senyawa kimia dengan aturan IUPAC pada tabel LKPD. Siswa yang memiliki keterampilan proses dengan persentase terendah yaitu $80 \%$ (sangat baik) adalah pada aspek interpretasi, pada aspek ini siswa mampu menghubungkan aturan penamaan senyawa IUPAC dengan baik. Pada observasi yang keempat ini rata-rata keterampilan proses sains siswa pada materi tatanama senyawa dikategorikan sangat baik.

Hasil rekapitulasi data observasi siswa dapat dilihat pada gambar 5 berikut ini

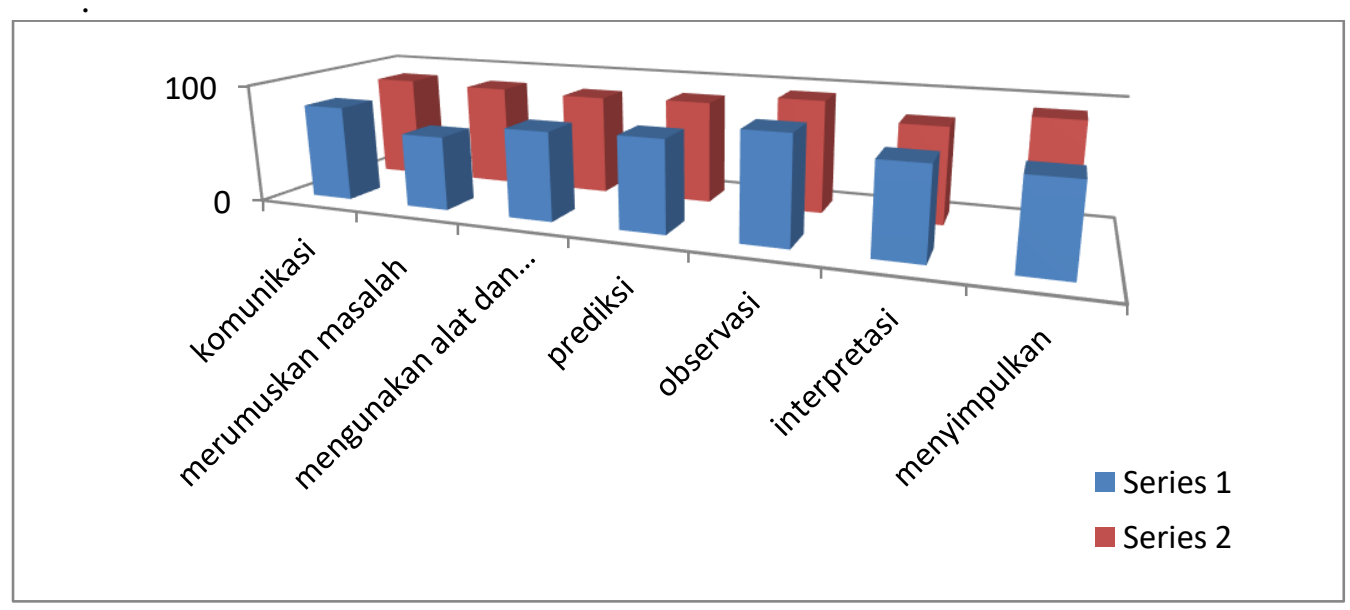

Gambar 5. Diagram Rekapitulasi Data Hasil Observasi Tes Keterampilan Proses Sains

Secara keseluruhan rekapitulasi data hasil observasi dapat digambarkan dalam gambar 6 sebagai berikut. 


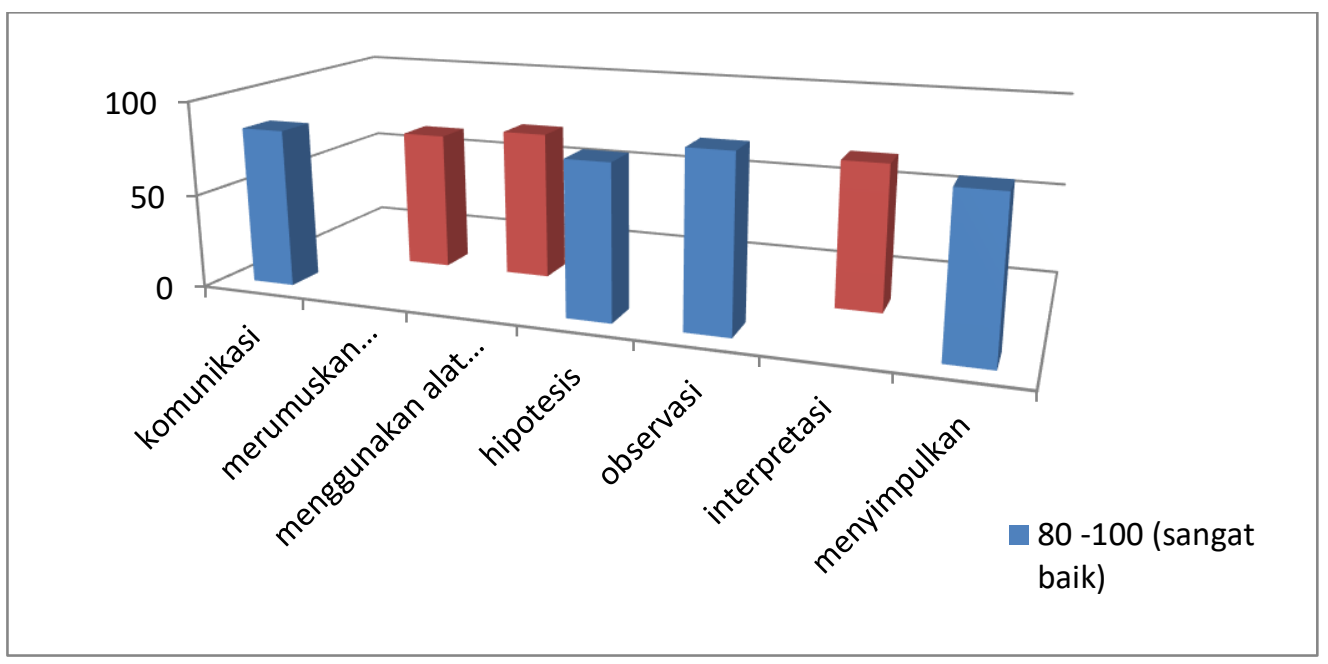

Gambar 6. Diagram Rekapitulasi Data Hasil Observasi Tes Keterampilan Proses Sains

Dari hasil observasi siklus I dan II diperoleh data hasil penelitian pada lembar observasi dari semua aspek keterampilan proses sains siswa terdapat aspek tertinggi dan terendah. Aspek mengamati/ observasi merupakan aspek tertinggi dengan nilai persentase rata- rata sebesar 91\% (gambar 6). Hal ini karena siswa diajak atau berinteraksi langsung pada objek atau peristiwa sesungguhnya. Sehingga siswa merasa tertarik dan bersemangat ketika kegiatan pengamatan (observasi). Aspek merumuskan masalah merupakan aspek terendah dengan nilai presentase rata- rata sebesar $74 \%$. Hal ini terjadi karena siswa belum terbiasa dalam merumuskan masalah sehingga siswa merasa kesulitan. Mereka terbiasa mengandalkan guru dalam belajar. Hasil dari semua aspek keterampilan proses sains memperoleh ratarata persentase $81 \%$ yang dikategorikan sangat baik.

Dalam penelitian ini dilakukan analisis skor N Gain, pada pembelajaran keterampilan proses sains yang digunakan untuk menghitung peningkatan keterampilan proses siswa. Keterampilan proses sains siswa memperoleh nilai $\mathrm{N}$ Gain sebesar 0,52 dan dikategorikan sedang.

\subsection{Data Hasil Belajar Siswa}

Data hasil belajar siswa dapat dilihat pada gambar 7 sebagai berikut.

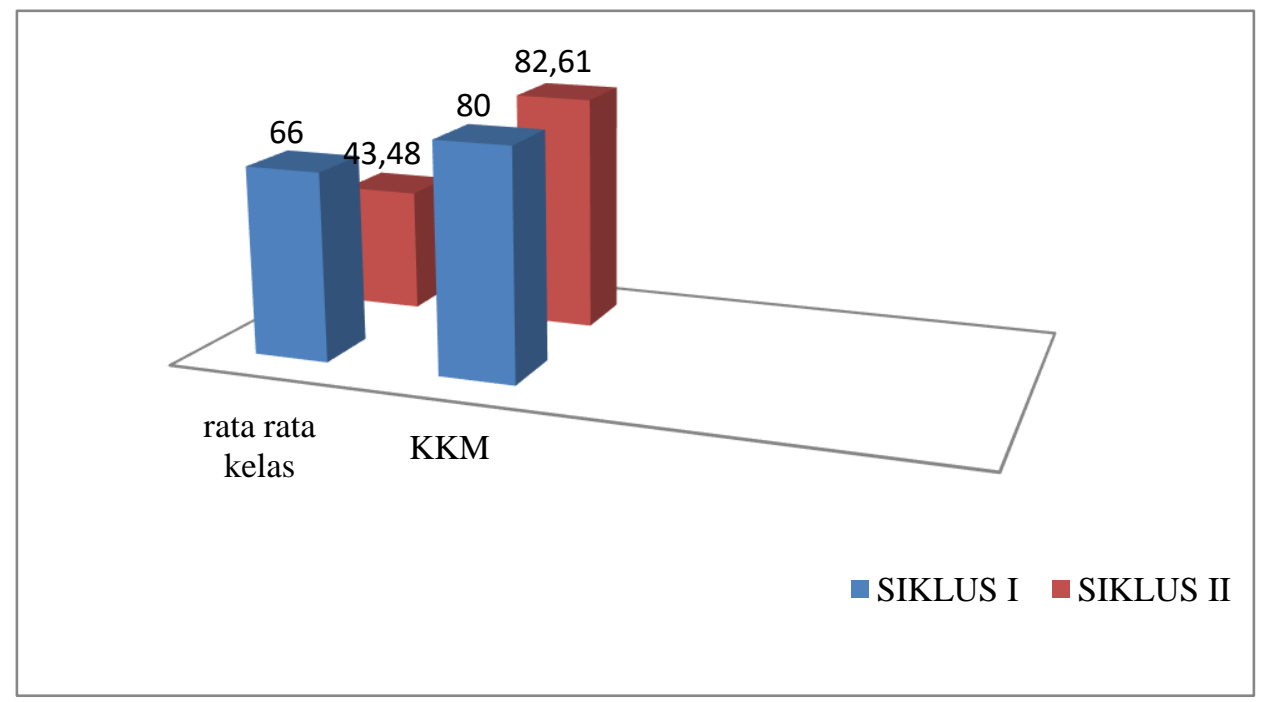


Gambar 7. Diagram Hasil belajar Siswa

Gambar 7 menunjukkan bahwa rata-rata kelas pada siklus I diperoleh skor sebesar 66\%, sedangkan pada siklus II diperoleh skor $80 \%$, maka rata-rata kelas meningkat menjadi 14,13\% sedangkan persentase ketercapaian KKM pada siklus I sebesar 43,48\% dan pada siklus II sebesar $82,61 \%$. Pada siklus I siswa yang mendapatkan nilai $\geq 70$ sebanyak 10 orang siswa, pada siklus II siswa yang mendapatkan nilai $\geq 70$ sebanyak 19 orang siswa. Masih ada 4 orang siswa yang belum memperoleh nilai KKM, hal ini disebabkan siswa masih bergantung pada teman kelompoknya untuk mengerjakan tugas-tugas pada LKPD.

Dengan hasil peningkatan keterampilan proses sains siklus I dan II yang memperoleh nilai Gain 0,52 dengan kategori sedang, 17\% siswa dari 23 siswa tidak terjadi peningkatan keterampilan proses sains. Keempat sisws tersebut dari pengamatan individual sulit untuk mengikuti proses pembelajaran.

Secara garis besar pembelajaran model inkuiri dengan keterampilan proses saian dapat digunakan dalam materi redoks.

\section{SIMPULAN DAN SARAN}

\subsection{Simpulan}

Berdasarkan hasil penelitian dapat disimpulkan bahwa:

1. Berdasarkan hasil lembar observasi dari semua aspek Keterampilan Proses Sains yang terukur terlihat bahwa aspek mengamati (observasi) merupakan aspek yang tertinggi yang dicapai oleh siswa yaitu dengan nilai rata- rata $91 \%$ sedangkan aspek yang terendah yang dicapai siswa yaitu aspek merumuskan masalah dengan nilai rata- rata $74 \%$.

2. Berdasrkan hasil lembar observasi dari semua aspek Keterampilan proses Sains diperoleh nilai ratarata sebagai berikut, aspek komunikasi sebesar $84 \%$, aspek merumuskan masalah sebesar $74 \%$, aspek menggunakan alat dan bahan sebesar $79 \%$, aspek menafsikan/hipotesis sebesar $81 \%$, aspek observasi/mengamati sebesar $91 \%$, aspek interpretasi sebesar $77 \%$, aspek menyimpulkan sebesar $82 \%$.

\subsection{Saran}

Berdasarkan hasil penelitian yang telah diperoleh, maka diajukan beberapa saran sebagai berikut:

1. Perlu dilakukan penelitian lebih lanjut mengenai penerapan model Inkuiri dalam pembelajaran kimia dengan kajian materi yang lebih luas dengan perluasan indikator keterampilan proses sains yang diteliti dan ranah efektifnya.

2. Hendaknya perlu ditambahkan pertanyaan-pertanyaan yang menggiring siswa supaya mampu merumuskan masalah dengan baik.

\section{DAFTAR PUSTAKA}

Arikunto, 2007, Prosedur Penelitian, Suatu Pendekatan Praktik, edisi Revisi VI, Jakarta, Rineka Cipta Diah Kusumaningsih, (2011). Upaya Meningkatkan Kemampuan Berpikir kritis Siswa. Universitas Negeri Yogyakarta.

Iswanto, 2012. Metodologi Penelitian Kuantitatif. Yogyakarta, pustaka Belajar

Luluk Mufidah. 2014. Pembelajaran Inkuiri Terbimbing dengan Program Moodle untuk Meningkatkan Motivasi dan Hasil Belajar Siswa. Jurnal Pendidikan Sains,2 (1): 18-27. 
Nanda Maikristina, dkk. 2013. Pengaruh Penggunaan Model Pembelajaran Inkuiri Terbimbing Terhadap Hasil Belajar dan Keterampilan Proses Sains Siswa Kelas XI IPA SMAN 3 Malang pada Materi Hidrolisis Garam. Jurnal Pendidikan Kimia,2 (2): 1-8.

Ulya Dewi Annur, dkk. 2012. Upaya Peningkatan Keterampilan Proses Sains dan Prestasi Belajar Siswa SMP Negeri 21 Malang Melalui Implementasi Pembelajaran Inkuiri Terbimbing Pada Materi Kalor. Jurnal Pendidikan Fisika, 2 (1): 1-9.

Wenni Jayanti, 2013, Deskripsi Keterampilan Proses Sains Pelajaran Kimia Dalam Model Inkuiri Terbimbing Berbantuan Flash Pada Siswa SMA, Pontianak: UNTAN. 